\title{
The Effectiveness of Google Classroom Among EFL Students in Jordan: An Innovative Teaching and Learning Online Platform
}

\author{
https://doi.org/10.3991/ijet.v15i11.12865 \\ Abeer Hameed Albashtawi $\left({ }^{(}\right)$ \\ Luminus Technical University College, Irbid, Jordan \\ abeerbashtawillegmail.com \\ Khaleel Bader Al Bataineh \\ Irbid National University, Irbid, Jordan
}

\begin{abstract}
This study investigated the effect of using Google Classroom on the reading and writing performance of diploma students with English as a Foreign Language (EFL) in Jordan. It aimed to investigate the attitudes of students toward using Google Classroom as an innovative online platform. A total of 26 EFL Syrian diploma students participated in this study; the participants sat in one intact group. The researchers employed a quasi-experimental design and onegroup pretest-posttest design based on the quantitative data. The data were collected through a reading and writing test and a questionnaire. According to the results of the study, Google Classroom improved the reading and writing performance of Syrian students. Students showed positive attitudes toward using Google Classroom in terms of its ease of use, usefulness, and accessibility. Future studies should analyze the effectiveness of Google Classroom with respect to other contexts. This study affirmed the liability of utilizing Google Classroom in wider contexts.
\end{abstract}

Keywords - Attitude, Google Classroom, technology, online platform, performance

\section{Introduction}

Nowadays, students of higher education are increasingly connected to newer technologies for the purpose of reading and learning, which has encouraged researchers and web-designers to take advantage of this and develop more new technology. New technology is desired and perceived positively by most of the students (Al Bataineh, Banikalef, Abdullah, \& Albashtawi, 2019). However, new technology always brings changes in the lifestyle of students. For example, students are time-poorer and think about time constraints rather than educational opportunities as affirmed by Stafford (2011). As a result, an online learning platform has been regarded as a tool that can save time, teach social skills, teach self-learning and self-discovery, and motivate to stay in touch with the recent trends (Taylor, Hunter, Melton, \& Goodwin, 2011). 
Google Classroom is a newly recognized, innovative, and one of the best online platforms for learning and teaching. It was launched in 2014 by Google (Al-Maroof\& AlEmran, 2018). Google Classroom application has been accepted by the educational community to promote the e-learning process. It integrates technology into traditional classrooms. The widespread acceptance of this innovative technology has led to the emergence of literature data. Instructors can support their face to face classes with online learning through Google Classroom (Halverson, Spring, Huyett, Henrie, \& Graham, 2017).

Google Classroom is very helpful and effective and presents newer challenges in continuing education in different ways for both teachers and learners. First, it is available to anyone around the world with tools and applications that make up a package called Google Apps for Education. The tools include Gmail, Drive, and Docs (Northey, Bucic, Chylinski, \& Govind, 2015). Second, Google Classroom is known for its ease of use (Janzen, 2014) and for the ease of organizing work and saving time (Northey et al., 2015), it can be accessed from laptops, PCs, and mobiles very easily. According to the estimates, within the first 6 months of use, Google Classroom received approximately 30 million assignments from teachers and students. This shows that Google Classroom is highly recommended by the educational community (Northey et al., 2015). Finally, online learning platforms such as Google Classroom provide flexibility in scheduling, eliminate travel expenses, and can reach out to anyone who has access to it.

Although the use of technology has been appreciated by several researchers such as Heggart and Yoo (2018); Northey et al. (2015); and Everson, Gundlach, and Miller (2013), some educators do not perceive it to be as good as the traditional method of teaching and learning (Pienta, 2016; Henrie, Halverson, \& Graham, 2015; Ranieri \&Manca, 2013;Kitsantas\&Dabbagh, 2011). Northey et al. (2015, p. 172) stated that blended learning might be able to create a learning environment focusing on students and is supported by in-class and out-of-class activities. Furthermore, Heggart and Yoo (2018) and Everson, Gundlach, and Miller (2013) affirmed that digital materials could engage students in blended learning contexts. However, Pienta (2016, p. 2) expressed his worries regarding the opportunities that students might find outside the classroom to complete their work. Likewise, Halverson et al. (2017) identified some challenges using online learning, for example, the students' privacy, the difference between the learning goals of the students and the institution in addition to the motives of the students which might not be compatible with the institution. In tandem with this, the notion of conflict between students' goals and institutions' goals was also pointed out by Manca and Ranieri (2013) and Dabbagh and Kitsantas (2012).

To sum up, it is noteworthy that Google Classroom deserves to be examined by researchers. So far, most of the studies have examined the students and teachers' attitudes toward using and accepting Google Classroom. To the best of our knowledge, this is the first study to investigate the effect of Google Classroom on the reading and writing performance of students with English as a Foreign Language (EFL) in Jordan. This study is also the first to analyze the attitudes of students toward using Google Classroom in Jordan. 
In this study, we investigated the effect of using Google Classroom on the performance of reading and writing among diploma students with EFL at Luminus Technical University College in Irbid, Jordan. We also aimed to investigate their attitudes toward using Google Classroom in terms of its ease of use, usefulness, and accessibility. We attempted to answer the following three research questions:

1. What is the effect of Google Classroom on the reading performance of EFL students?

2. What is the effect of Google Classroom on the writing performance of EFL students?

3. What are the attitudes of EFL students toward using Google Classroom?

\section{$2 \quad$ Methods}

This study is theoretically based on the technology acceptance model (TAM) that was initially developed to investigate the acceptance of new technology. This is a commonly used model that was developed by Davis (1989) (Arbaugh, 2010). It is based on the theory of reasoned action (TRA), which investigates the way people perceive the new technology in terms of its usefulness and ease of use. While usefulness measures the degree of improvement in students' performance after using the new technology, ease measures the degree of accessibility to the new technology. In this study, we employed TAM to measure the usefulness and acceptance of Google Classroom among EFL students.

In this study, we implemented a quasi-experimental design and based on it, we used one group pretest-posttest design to analyze the data. We followed a two-phase explanatory sequential design. During the first phase, the data were collected through a reading and writing test (consisting of two separate parts: reading and writing) that was conducted before and after the implementation of Google Classroom. During the second phase, we presented a questionnaire to obtain responses based on the five-point Likert response scale system to investigate the attitudes of students toward using Google classroom in terms of its ease of use, usefulness, and accessibility; this was undertaken only after the intervention. A quasi-experimental design is useful in the analysis of one group of participants with no comparison group.

\subsection{Participants and study context}

The present study was conducted at Luminus Technical University College (LTUC) in Irbid, Jordan, in the academic year 2018-2019. A total of 26 EFL diploma students from the Business Administration Department who registered for the Advanced Reading course were included. Students were taught from the prescribed book entitled Pathways 2: Reading, Writing, and Critical Thinking. It contains a series of guided lessons to develop language skills and critical thinking. This book contains information based on authentic and relevant information from the National Geographic. The course was taught on different days, three hours face-to-face in the classroom and one hour in the learning and teaching center. 
The students were in the age group of 25-29 years and were homogenous in terms of mother tongue (Arabic), cultural background, number of years of studying EFL in Syrian schools, and were refugees.

\subsection{Sampling and data collection}

This study utilized a convenience sampling method, which is also known as purposive, selective, judgmental, or subjective sampling. It reflects the method of nonprobability sampling, which focuses on sampling techniques where participants are chosen based on their availability and the convenience of the researcher. Although this type of sampling is less desirable than that of other types of sampling techniques, it can address the research questions based on the particular characteristics of the population of interest (Creswell, 1998). In this study, we used the convenience sampling technique because it was the only available technique for the Advanced Reading course.

We collected the quantitative data by conducting a reading and writing test and through a questionnaire. The reading and writing test aided in the collection of data from instructors regarding the performance of the students in reading and writing, and the questionnaire was used to obtain data regarding the attitudes of the students toward the Google Classroom App. The researchers adopted a standardized reading and writing test. The reading part of the test consisted of 15 multiple-choice questions, whereas the writing part consisted of 15 fill in the blank questions. To achieve the reliability of the tests, the researchers computed their psychometric characteristics (difficulty parameters and discrimination parameters) after applying them on a pilot sample of 22 students. As Lord (1980, p. 21) confirmed that only questions with difficulty parameters ranged between 0.20 and 0.85 and discrimination parameters ranged between 0.20 and 0.80 were acceptable, the results showed that all the test questions difficulty parameters and discrimination parameters were accepted.

Furthermore, we developed an attitude scale questionnaire to collect data on students' attitudes toward the app in terms of its ease of use, usefulness, and accessibility. It consisted of 16 items distributed among 3 domains: usefulness domain, ease of use domain, and accessibility domain. The questionnaire was validated by asking a jury of university instructors to give their remarks about the questionnaire. Their suggestions were taken into consideration by deleting and adding some items.

The reliability of the questionnaire was tested by choosing a pilot sample consisting of 22 students. Cronbach's alpha was estimated to test the reliability of the scale, and its value ranged between 0.84 and 0.89 in the case of domains and was 0.91 for the whole scale. This showed that there was a high reliability of the questionnaire (George \& Mallery, 2003).

\subsection{Implementation of google classroom intervention}

In this study, the instructor of the Advanced Reading course met the students during the third week after adding and dropping period and introduced the requirements for passing the course. Students were informed that they should attend a three-hour faceto-face class with the instructor, and one -hour in the learning and teaching center. After 
completing each unit, the students were asked to do one writing assignment in addition to reading assignments. Google forms and google documents were used. As this was the first exposure of students to Google Classroom, the instructor assigned the students to go to the learning and teaching center for the second class. Students had the opportunity to choose a suitable time according to their convenience and free time. The instructor asked each student to create a new Gmail account. Once the students created the Gmail accounts, they were provided with the code of the class to join it. Then, the instructor explained how to use Google Classroom during the course to submit their assignments.

\subsection{Data analysis}

We used the Statistical Package for the Social Sciences (SPSS Version 21) software to answer the three research questions of this study. Means, standard deviations, frequencies, and percentages were computed for the demographic data and for the attitudes' data. A paired sample $t$-test was conducted to find the significant differences between the pretest and posttest reading and writing assignments.

\section{$3 \quad$ Results}

Research question 1: What is the effect of google classroom on the reading performance of EFL students?

We examined the effect of Google Classroom on the reading performance of EFL students by analyzing their pretest and posttest scores in the academic reading test. Table 1 shows the students' overall scores of the pretest and posttest reading performance. Table 2 presents the results of the paired samples $t$-test scores, which revealed a significant difference between the means of the students' pretest and posttest scores. This indicates that the posttest scores were better than the pretest scores with an effect size of about $53.60 \%$.

Table 1. Mean and standard deviation of the students' pretest and posttest reading test

\begin{tabular}{|l|c|c|}
\hline \multicolumn{1}{|c|}{ Reading Test } & Mean & Standard Deviation \\
\hline Pretest & 8.54 & 1.60 \\
\hline Posttest & 13.12 & 1.37 \\
\hline
\end{tabular}

Table 2. Results of paired sample $t$-test for the students' pretest and posttest reading test

\begin{tabular}{|l|c|c|c|c|c|c|}
\hline \multicolumn{1}{|c|}{ Test } & Mean & Standard Deviation & df & (t) Value & Significance & Size Effect \\
\cline { 1 - 6 } Pretest & 8.54 & 1.60 & \multirow{2}{*}{25} & 9.326 & $0.000^{*}$ & $53.60 \%$ \\
\hline Posttest & 13.12 & 1.37 & & & & \\
\hline
\end{tabular}

*Significant at $(\alpha \leq 0.05)$.

Research question 2: What is the effect of google classroom on the writing performance of EFL students?

We examined the effect of Google Classroom on the writing performance of EFL students by analyzing their pretest and posttest scores in the writing test. Table 3 shows 
the students' overall pretest and posttest scores of their writing performance. Table 4 shows paired samples $t$-test scores, which revealed a significant difference between the means of pretest and posttest scores in writing. This shows that the posttest scores were better than that of the posttest scores with an effect size of about $56.77 \%$.

Table 3. Means and standard deviations of the students' pretest and posttest writing test

\begin{tabular}{|l|c|c|}
\hline \multicolumn{1}{|c|}{ Writing Test } & Mean & Standard Deviation \\
\hline Pretest & 7.38 & 1.80 \\
\hline Posttest & 11.58 & 1.28 \\
\hline
\end{tabular}

Table 3 shows that there are differences between the mean scores of the students' pretest and posttest writing tests. To test the significance of these differences, pairedsamples $t$-test was used. Table 4 presents the results.

Table 4. Paired samples $t$-test results for the students' pretest and posttest writing test

\begin{tabular}{|l|c|c|c|c|c|c|}
\hline \multicolumn{1}{|c|}{ Test } & Mean & $\begin{array}{c}\text { Standard Devia- } \\
\text { tion }\end{array}$ & df & $(\boldsymbol{t})$ Value & Significance & Size Effect \\
\hline Pretest & 1.80 & 7.38 & \multirow{2}{*}{25} & 10.201 & $0.000^{*}$ & $56.77 \%$ \\
\hline Posttest & 1.28 & 11.58 & & & \\
\hline
\end{tabular}

*Significant at $(\alpha \leq 0.05)$.

Table 4 shows that there is a significant difference between the means of the students' pretest and posttest writing scores, with posttest an effect size of about $56.77 \%$.

Research question 3: What are the attitudes of EFL students toward using google classroom?

We quantitatively examined the attitudes of EFL students toward Google Classroom by analyzing students' responses to 16 items in 3 domains (usefulness, ease of use, and accessibility) at posttest after the implementation of Google Classroom. To specifically address this, descriptive statistics (means and standard deviations) of the students' responses on the attitudes toward using Google Classroom questionnaire domains were computed.

Table 5. Means and standard deviations of students' responses on the posttest scores.

\begin{tabular}{|c|l|c|c|c|c|}
\hline No. & \multicolumn{1}{|c|}{ Dependent Variables } & Mean* & Standard Deviation & \multicolumn{1}{|c|}{ Degree } & Rank \\
\hline 2 & Attitudes in term of its Ease of Use Domain & 4.04 & 0.62 & High & 1 \\
\hline 1 & Attitudes in term of its Usefulness Domain & 3.92 & 0.78 & High & 2 \\
\hline 3 & Attitudes in term of Access Domain & 3.91 & 0.64 & High & 3 \\
\hline \multicolumn{2}{|l}{ Total } & 3.94 & 0.60 & High & - \\
\hline
\end{tabular}

*Out of 5 scores

Table 5 shows that ease of use domain was ranked first based on the mean value $(4.04 \pm 0.62)$ and the usefulness domain $(3.92 \pm 0.78)$ was ranked as the second. However, mean score of accessibility (3.91 0.64$)$ was ranked as the least. These results indicate that the overall mean score of the students' responses was $3.94 \pm 0.60$. 
Table 6 shows the descriptive statistics of the students' responses on their attitudes in terms of the ease of use, usefulness, and accessibility domains.

Table 6. Descriptive statistics of students' responses on their attitudes in terms of items in usefulness domain.

\begin{tabular}{|c|c|c|c|c|c|}
\hline No. & Dependent Variables & Means* & $\begin{array}{l}\text { Standard } \\
\text { Deviation }\end{array}$ & $\begin{array}{l}\text { Practice } \\
\text { Degree }\end{array}$ & Rank \\
\hline \multicolumn{6}{|c|}{ Usefulness Items } \\
\hline 7 & I like doing activities through Google Classroom & 4.34 & 0.89 & High & 1 \\
\hline 1 & $\begin{array}{l}\text { I look forward to using Google Classroom in other } \\
\text { classes! }\end{array}$ & 4.15 & 0.80 & High & 2 \\
\hline 9 & $\begin{array}{l}\text { There is value in using Google Classroom for } \\
\text { teaching and learning purposes. }\end{array}$ & 3.96 & 0.76 & Mid & 3 \\
\hline 2 & I find Google Classroom! helpful. & 3.92 & 0.81 & High & 4 \\
\hline 3 & I find Google Classroom! useful. & 3.86 & 0.79 & High & 5 \\
\hline 5 & $\begin{array}{l}\text { Google Classroom helps me in improving my writing } \\
\text { skills }\end{array}$ & 3.83 & 0.86 & High & 6 \\
\hline 4 & $\begin{array}{l}\text { Google Classroom helps me in improving my reading } \\
\text { skills }\end{array}$ & 3.81 & 1.01 & High & 7 \\
\hline 6 & Google Classroom activities are helpful & 3.79 & 0.78 & High & 8 \\
\hline 8 & $\begin{array}{l}\text { Google Classroom should be used in higher } \\
\text { education. }\end{array}$ & 3.58 & 0.91 & High & 9 \\
\hline \multicolumn{6}{|c|}{ Ease of Use Items } \\
\hline 10 & Using Google Classroom application is easy & 4.12 & 0.76 & High & 1 \\
\hline 11 & I feel instructions of the activities are clear & 4.02 & 0.88 & High & 2 \\
\hline 12 & $\begin{array}{l}\text { I feel positive when submitting my assignment } \\
\text { through Google Classroom }\end{array}$ & 3.99 & 0.78 & High & 3 \\
\hline \multicolumn{6}{|c|}{ Access Items } \\
\hline 14 & $\begin{array}{l}\text { Google classroom application is available on my } \\
\text { smartphone }\end{array}$ & 4.11 & 0.96 & High & 2 \\
\hline 16 & $\begin{array}{l}\text { Using Google Classroom in all courses that have } \\
\text { assignment is better than paper-based assignments }\end{array}$ & 3.93 & 0.77 & High & 3 \\
\hline 13 & $\begin{array}{l}\text { I respond as quickly as possible to each assignment or } \\
\text { question in Google Classroom }\end{array}$ & 3.75 & 0.81 & High & 1 \\
\hline 15 & I can login into Google Classroom anytime anywhere & 3.76 & 0.87 & High & 2 \\
\hline
\end{tabular}

As shown in Table 6 , the overall attitudes of the students were positive toward Google Classroom in terms of its usefulness, use of use, and accessibility.

\section{Discussion}

Although Google Classroom has been widely used by the educational community, very few studies have studied its effectiveness. Furthermore, most of the studies were restricted to examining the attitudes of students and teachers toward Google Classroom. Examples on these included; Apriyanti, Syarif, Ramadhan, Zaim, and Agustina (2019); Heggart and Yoo (2018); Ventayen, Estira, De Guzman, Cabaluna, and Espinosa (2018); Al-Emran and Malik (2016); Al-Maroof and Al-Emran (2018); Wijaya (2016)Shaharanee, Jamil, and Rodzi (2016b), and Iftakhar (2016). To the best of our 
knowledge, this is the first experimental study to examine the effect of Google Classroom on reading and writing performance of EFL students in Jordan. It also attempted to investigate the attitudes of the students toward using Google Classroom in terms of its ease of use, usefulness, and accessibility.

The results of the first and the second research questions showed that Google Classroom positively affected the reading and writing performance of EFL students. The reading and writing test revealed that the difference between the mean pretest and posttest scores of the reading and writing test was significant, with a posttest effect size of about $53.60 \%$ and $56.77 \%$ for reading and writing, respectively. Apriyanti et al. (2019) obtained similar results and they affirmed that Google Classroom application is effective in facilitating the process of teaching the English Business Writing class in a paperless environment. However, their study was a descriptive one when compared to the present study.

These improvements in the students' reading and writing performance can be attributed to several factors. First, the good implementation of Google Classroom intervention, where the instructors were able to use it together with face-to-face classes and upload the appropriate materials. Second, the length of the intervention program played a positive role in the students' performance, which lasted for 12 weeks. Third, Google Classroom features are not complicated to understand and implement. This finding was supported by Iftakhar (2016) and Janzen (2014). Finally, there was a positive attitude among students in using Google Classroom in terms of its ease of use, usefulness, and accessibility. Similar effectiveness of Google Classroom was reported by Heggart and Yoo (2018). Their results revealed that Google Classroom increased students questioning and improved students' engagement in the classroom.

The results of the third research question showed that students' attitudes toward Google Classroom in terms of its usefulness, ease of use, and accessibility were positive. According to the results, the usefulness of Google Classroom was ranked first, ease of use was ranked second, and accessibility was ranked as third by the students. These results came in tandem with Al-Emran and Malik (2016), Al-Maroof and AlEmran (2018), Heggart and Yoo (2018), Hemrungrote, Jakkaew, and Assawaboonmee (2017), Iftakhar (2016), Shaharanee et al. (2016a), Ventayen et al. (2018), and Wijaya, (2016), who affirmed the overall positive attitudes of students toward Google Classroom. Thus, the features of Google Classroom have encouraged students to accept it. Ventayen et al. (2018) investigated the practicality of Google Classroom in adopting and employing it among students in the Philippines. Based on their results, the respondents asserted that Google Classroom was useful. Accordingly, the study posited that the e-learning platform for Pangasinan State University, Lingayen Campus was fruitful. Al-Emran and Malik (2016) conducted a similar survey in the Omani EFL context and collected data regarding the usage of Google Classroom. According to their results, Google Applications were positively perceived by both administrative and academic personnel. In addition, Google Applications were significantly welcomed by the institutions of higher education. Al-Maroof and Al-Emran (2018) studied the acceptance of Google Classroom by students of Al Buraimi University College, Oman. Their results demonstrated a positive effect of both perceived ease of use and usefulness among the students. 
Furthermore, Shaharanee, Jamil, and Rodzi (2016a) studied the effectiveness of active learning activities for data mining subjects by applying Google Classroom application. Their results affirmed that most of the students were satisfied with the tools of Google Classroom. In summary, the features of Google Classroom, the clear and good implementation of the program, and the positive attitudes of students and instructors toward Google Classroom assisted in the improvement of the students' reading and writing performance. Thus, it is essential to understand the objectives of employing technology in the classroom. Furthermore, understanding the method of using technology in an appropriate way would help in improving the teaching and learning process.

\section{Conclusion}

According to the results of our study, Google Classroom is an innovative and effective online platform for improving EFL students' reading and writing performance. Furthermore, students perceived Google Classroom positively in terms of its usefulness, ease of use, and accessibility. Different factors helped in the improvement of reading and writing performance. For example, the method of implementing the intervention of Google Classroom, the duration of implementation, which lasted for one semester, ensured the probability of getting good results, the effective set of Google Classroom features, and the students' positive attitudes toward Google Classroom in terms of its usefulness, ease of use, and accessibility.

In this digital age, it is inevitable to live without experiencing emergent teaching and learning online platforms. Thus, understanding new technology and the way it works in classrooms has become a demand as all institutions of higher education try to experience new online platforms. The results of this study demonstrated a real example of using Google Classroom as an emergent online platform in the EFL classroom. Employing technology entails understanding it to make a real advantage.

This study has some limitations. First, the results of the study cannot be generalized because the sample was small and data collection was restricted to the students of Luminus Technical University College. Therefore, future studies should be performed with a larger sample size and in different contexts. Furthermore, future research should consider teachers' perceptions toward utilizing Google Classroom. Different quantitative and qualitative methods of data collection should be included.

Experimental studies should be focused on for several reasons. First, they could provide a clear framework for applying Google Classroom in classrooms. Second, experimental studies could help in understanding the way teachers can utilize this new tool. Finally, experimental studies could provide teachers, educators, and policymakers with constructive feedback regarding the effectiveness of this new online platform.

\section{References}

[1] Al-Emran, M., \& Malik, S. I. (2016). The Impact of Google Apps at Work: Higher Educational Perspective. iJIM, 10(4), 85-88. https://doi.org/10.3991/ijim.v10i4.6181 
[2] Al-Maroof, R. A. S., \& Al-Emran, M. (2018). Students Acceptance of Google Classroom: An Exploratory Study using the PLS-SEM Approach. International Journal of Emerging Technologies in Learning, 13(6). https://doi.org/10.3991/ijet.v13i06.8275

[3] Al Bataineh, K. B., Banikalef, A., Abdullah, A. E., \&Albashtawi, A. H. (2019). The Effect of Blended Learning on EFL Students' Grammar Performance and Attitudes: An Investigation of Moodle. Arab World English Journal (AWEJ) Volume, 10. https://doi.org/10. 24093/awej/vol10no1.27

[4] Arbaugh, J. B. (2010). Online and blended business education for the 21st century: Current research and future directions. Elsevier

[5] Apriyanti, D., Syarif, H., Ramadhan, S., Zaim, M., \& Agustina, A. (2019). TechnologyBased Google Classroom in English Business Writing Class. Paper presented at the Seventh International Conference on Languages and Arts (ICLA 2018). https://doi.org/10. 2991/icla-18.2019.113

[6] Creswell, J. (1998). W. (1998). Qualitative inquiry and research design: Choosing among five traditions, 2.

[7] Dabbagh, N., \&Kitsantas, A. (2012). Personal Learning Environments, social media, and self-regulated learning: A natural formula for connecting formal and informal learning. The Internet and higher education, 15(1), 3-8. https://doi.org/10.1016/j.iheduc.2011.06.002

[8] Eastin, M. S., \& LaRose, R. (2000). Internet self-efficacy and the psychology of the digital divide. Journal of computer-mediated communication, 6(1), JCMC611. https://doi.org/10. 1111/j.1083-6101.2000.tb00110.x

[9] Everson, M., Gundlach, E., \& Miller, J. (2013). Social media and the introductory statistics course. Computers in Human Behavior, 29(5), A69-A81. https://doi.org/10.1016/j.chb. 2012.12.033

[10] George, D., \& Mallery, M. (2003). Using SPSS for Windows step by step: a simple guide and reference. https://doi.org/10.4324/9780429056765

[11] Halverson, L. R., Spring, K. J., Huyett, S., Henrie, C. R., \& Graham, C. R. (2017). Blended learning research in higher education and K-12 settings. Learning, design, and technology: An international compendium of theory, research, practice, and policy, 1-30. https://doi.org/10.1007/978-3-319-17727-4 31-1

[12] Heggart, K. R., \&Yoo, J. (2018). Getting the Most from Google classroom: A pedagogical framework for tertiary educators. Australian Journal of Teacher Education, 43(3), 9. https://doi.org/10.14221/ajte.2018v43n3.9

[13] Hemrungrote, S., Jakkaew, P., \&Assawaboonmee, S. (2017). Deployment of Google Classroom to enhance SDL cognitive skills: A case study of introduction to information technology course. Paper presented at the 2017 International Conference on Digital Arts, Media, and Technology (ICDAMT). https://doi.org/10.1109/icdamt.2017.7904961

[14] Henrie, C. R., Halverson, L. R., \& Graham, C. R. (2015). Measuring student engagement in technology-mediated learning: A review. Computers \& Education, 90, 36-53. https:// doi.org/10.1016/j.compedu.2015.09.005

[15] Iftakhar, S. (2016). Google Classroom: what works and how? Journal of Education and Social Sciences, 3(1), 12-18.

[16] Janzen, M. (2014). Hot Team: Google Classroom. Retrieved from tlt. psu. edu.

[17] Kitsantas, A., \&Dabbagh, N. (2011). The role of Web 2.0 technologies in self-regulated learning. New directions for teaching and learning, 2011(126), 99-106. https://doi.org/ $\underline{10.1002 / \mathrm{tl} .448}$

[18] Manca, S., \& Ranieri, M. (2013). Is it a tool suitable for learning? A critical review of the literature on Facebook as a technology-enhanced learning environment. Journal of Computer Assisted Learning, 29(6), 487-504. https://doi.org/10.1111/jcal.12007 
[19] Northey, G., Bucic, T., Chylinski, M., \& Govind, R. (2015). Increasing student engagement using asynchronous learning. Journal of Marketing Education, 37(3), 171-180. https://doi.org/10.1177/0273475315589814

[20] Pienta, N. J. (2016). A "flipped classroom" reality check: ACS Publications.

[21] Ranieri, M., \&Manca, S. (2013). I social network nell'educazione: basiteoriche, modelliapplicativi e lineeguida: Edizioni Centro Studi Erickson.

[22] Shaharanee, I. N. M., Jamil, J. M., \&Rodzi, S. S. M. (2016a). The application of Google Classroom as a tool for teaching and learning. Journal of Telecommunication, Electronic and Computer Engineering (JTEC), 8(10), 5-8. https://doi.org/10.1063/1.4960909

[23] Shaharanee, I. N. M., Jamil, J. M., \&Rodzi, S. S. M. (2016b). Google classroom as a tool for active learning. Paper presented at the AIP Conference Proceedings. https://doi.org/ $\underline{10.1063 / 1.4960909}$

[24] Stafford, G. (2011). The unexpected transformations of Chinese international students in Australia.

[25] Ventayen, R. J. M., Estira, K. L. A., De Guzman, M. J., Cabaluna, C. M., \& Espinosa, N. N. (2018). Usability evaluation of google classroom: Basis for the adaptation of gsuite e-learning platform. Asia Pacific Journal of Education, Arts, and Sciences, 5(1), 47-51.

[26] Wijaya, A. (2016). Analysis of factors affecting the use of Google Classroom to support lectures. Paper presented at the 5th International Conference on Information Technology and Engineering Application (ICIBA2016).

\section{$7 \quad$ Authors}

Dr. Abeer Hameed Albashtawi is a senior lecturer at the Foundation and Support Programs Department at Luminus Technical University College. Her major research interests include applied linguistics, EFL, reading, vocabulary, motivation, and blended learning.

Dr. Khaleel Bader Al Bataineh is an associate Professor at the Faculty of Arts, Department of English Language and its Literature, Irbid National University, Irbid, Jordan. His research interests are applied linguistics, e- learning, blended learning, language in use, language analysis, speech acts and their role in communication and sociolinguistic behavior.

Article submitted 2019-12-23. Resubmitted 2020-02-17. Final acceptance 2020-02-21. Final version published as submitted by the authors. 